\title{
SISTEM PENGAMBILAN KEPUTUSAN KREDIT RUMAH DENGAN METODE FUZZYSAW MADM
}

\author{
${ }^{\# 1}$ Marganda Simarmata, ${ }^{\# 2}$ Dahlan Abdullah \\ ${ }^{\# 1}$ Program Studi Teknik Informatika STMIK Sisingamangaraja XII, Medan \\ ${ }^{\# 2}$ Program Studi Informatika Fakultas Teknik Universitas Malikussaleh, Aceh \\ E-mail : ${ }^{\# 1}$ gand_smart@yahoo.com, ${ }^{\# 2}$ dahlanlsw@gmail.com
}

\begin{abstract}
Abstrak
Persetujuan Kredit Perumahan oleh pelanggan pada sebuah bank sering terhambat dan lama karena proses persetujuan dilakukan dengan manual karena harus dikerjakan secara hati-hati sesuai dengan kriteria yang ditentukan. Kelemahan manual ini menjadi alasan perlunya Sistem Pengambilan Keputusan untuk menyetujui persetujuan KPR pada salah satu Bank. Dalam penelitian inisistem yang dibangun menggunakan metode Fuzzy Simple Additive Weighting Multiple Atribut Decission Making.Perancangan program aplikasi ini dibuat dengan menggunakan bahasa pemrograman Visual Studio 6.0dan perancangan database menggunakan Microsoft Accses2007 sertaSeagate Crystal Report 8,5 untuk pembuatan laporan atau output yang diperlukan.Hasil yang diperoleh dari sistem yang dirancang dapat membantu para manager perusahaan atau para pengambil keputusan untuk memutuskan calon pelanggan KPR dengan cepat, mudah dan akurat.
\end{abstract}

Kata kunci : SistemPendukung Keputusan, Kredit Perumahan, Fuzzy Simple Additive Weighting

\section{PENDAHULUAN}

Kredit Perumahan Rakyatmelibatkan dua hubungan hukum antara Debitur dengan Developer dan antara Debitur dengan Bank sebagai Kreditor dengan memenuhi beberapa syarat sesuai ketentuan yang berlaku dan atas kesepahaman antara kedua belah pihak. Beberapa hal yang harus dipenuhi antara lainpembayaran uang muka dengan besaran antara 10\% $-20 \%$ dari totalharga kepada pengembang, hal inidikarenakan Bank pada umumnya hanya memberikan kredit sebesar $80 \%$ dari total harga rumah, apabila rumah yang dibeli sedang dalam pembangunan atau belum siap dipindah tangankan oleh Developermaka dibuat suatu Perjanjian Pengikatan Jual Beli (PPJB), bila persetujuan kredit disetujui dan persyaratan telah lengkap maka dilakukan Perjanjian Kredit antara Debitur dengan Bank pemberi Kredit di hadapan Notaris dan beberapa syarat lainnya.Banyaknya kriteria atau syarat yang harus dipenuhi oleh calon pembeli menjadikan proses persetujuan kredit membutuhkan waktu yang lama.

Hal tersebut dapat diatasi dengan implementasi SPK dalam proses pengambilan keputusan dengan tujuan membantu manajer (decision maker) dalam pengambilan keputusan atas masalah semi terstruktur, mendukung pertimbangan manajer dan bukannya untuk menggantikan fungsi manajer, meningkatkan efektivitas keputusan yang diambil manajer lebih daripada perbaikan efisiensinya, kecepatan komputasi yang memungkinkan para pengambil keputusan untuk melakukan banyak komputasi secara cepat dengan biaya yang rendah, meningkatkan produktivitas, meningkatkan kualitas keputusan yang dibuat, meningkatkan daya saing serta mengatasi keterbatasan kognitif dalam pemrosesan data.

Semakin banyak data yang diakses maka makin banyak juga alernatif yang bisa dievaluasi. Semakin banyak alternatif semakin sulit membuat keputusan yang cepat, tepat dan akurat. Dengan bantuan sistem pengambilan keputusan maka analisis resiko dapat dilakukan dengan cepat, data dikumpulkan cepat dan dengan biaya yang lebih rendah. Dengan komputer, para pengambil keputusan bisa melakukan simulasi yang kompleks, memeriksa banyak skenario yang memungkinkan, dan menilai berbagai pengaruh secara cepat dan ekonomis yang mengarah kepada keputusan yang lebih baik. 


\section{METODE PENELITIAN}

Metodelogi penelitian yang dilakukan dalam penelitian ini adalah sebagai berikut:

1. Metodelogi Pengumpulan Data.

Pada tahap awal ini dilakukan pengumpulan data atau materi penulisan dengan cara:

a. Metode observasi yaitu pengamatan langsung pada objek permasalahan dilapangan dalam penelitian ini di sebuah bank.

b. Metode Interview (wawancara) yakni proses pengumpulan data dengan mewawancarai petugas bank terutama yang bertugas di bagian persetujuan aplikasi calon pembeli.

c. Metode Studi Literatur dengan melakukan penelitian keperpustakaan yang ada kaitannya dengan perancangan Sistem Pengambilan Keputusan Kredit Perumahan.

2. Perancangan Sistem Informasi.

Tahap Perancangan Sistem Informasi ini adalah :

a. Menggambarkan Diagram Konteks.

b. Menggambarkan DFD.

c. Menggambarkan Desain Database, Relasi antar tabel dan User Interface.

\section{HASIL DAN PEMBAHASAN}

\subsection{Analisa Sistem}

Pada bagian analisa sistem ini, penulis menjelaskan perbedaan antara sistem lama dengan perhitungan manual dan sistem baru secara terkomputerisasi.

\subsubsection{Sistem Lama}

Adapun kelemahan dari sistem lama menurut penulis adalah sebagai berikut:

1. Data calon pembeli yang mengajukan KPR tidak tersimpan secara terkomputerisasi dalam database.

2. Pengambilan keputusan untuk menentukan calon pembeli membutuhkan waktu yang lama.

3. Keputusan calon pembeli berpeluang terjadinya nepotisme walau kriteria yang disyaratkan tidak lengkap

\subsubsection{Sistem Baru}

Berdasarkan analisa pada sistem lama penulis merancang sistem baru yang menggantikan sistem lama. Adapun kelebihan dari sistem baru adalah sebagai berikut:

1. Proses data calon pembeli rumah dilakukan secara komputerisasi.

2. Meminimalisir terjadinya nepotisme antara oknum pihak bank dengan calon pembeli karena sistem akan membaca seluruh kriteria yang disyaratkan dalam pengajuan KPR

3. Pengambilan keputusan calon pembeli yang disetujui menjadi cepat

\subsection{Desain Sistem}

berikut:

Langkah-langkah perancangan Sistem Pengambilan Keputusan Kredit Rumah adalah sebagai

1. Menggambarkan diagram konteks antara calon pembeli dengan pihak bank atau operator pengguna sistem.

2. Menggambarkan DFD untuk menjelaskan lebih detail dari diagram konteks sistem yang dirancang.

3. Mengambarkan relasi antar tabel, interface input dan output sistem secara umum.

\subsection{Desain Logika}

Berikut rancangan design logika yang digunakan dalam rancangan Sistem Pengambilan Keputusan Kredit Rumah. 


\subsubsection{Diagram Konteks}

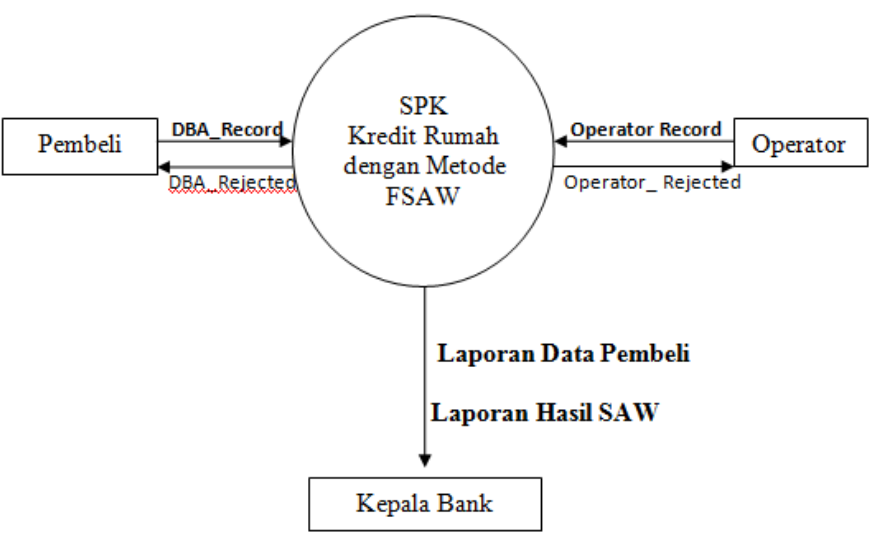

Gambar 1. Diagram Konteks

\subsubsection{Data Flow Diagram Level 0}

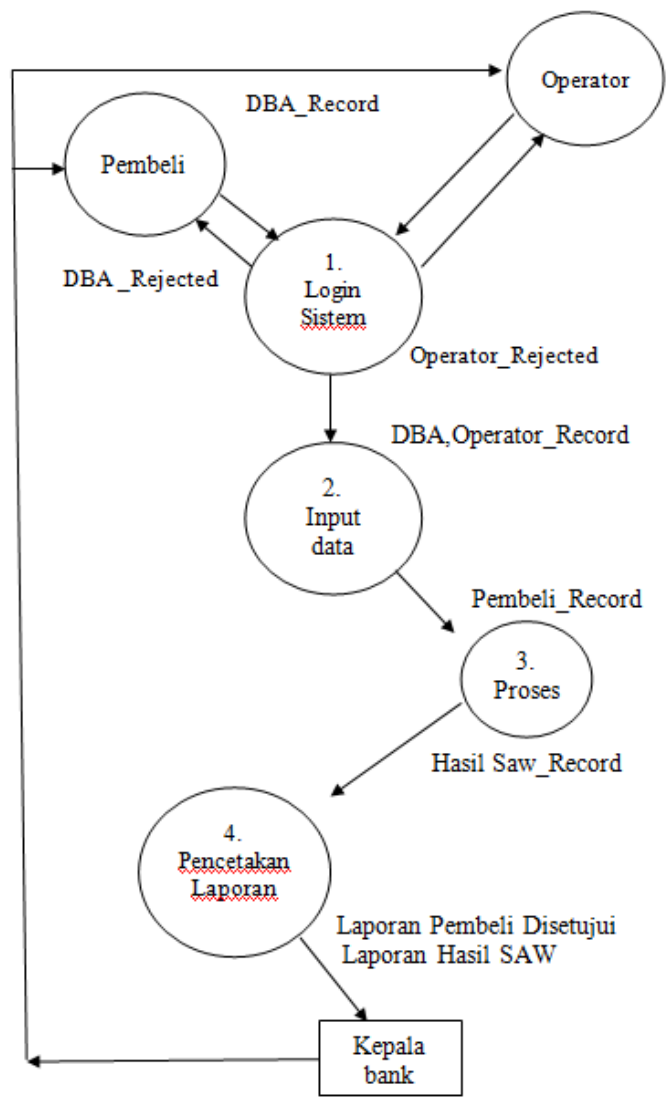

Gambar 2. Data Flow Diagram Level 0 


\subsection{Table Relationship}

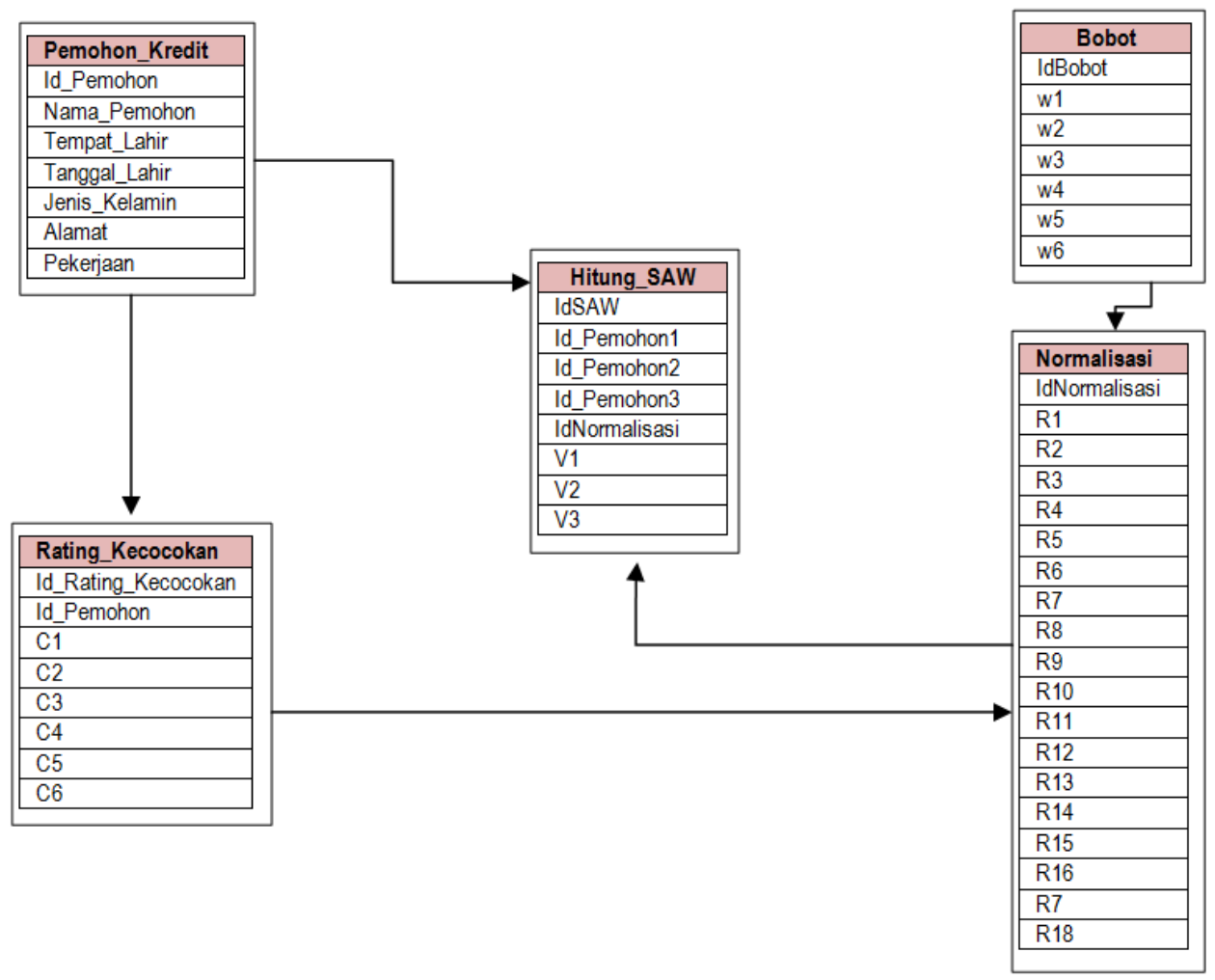

Gambar 3. Table Relationship

\subsection{Output Sistem}

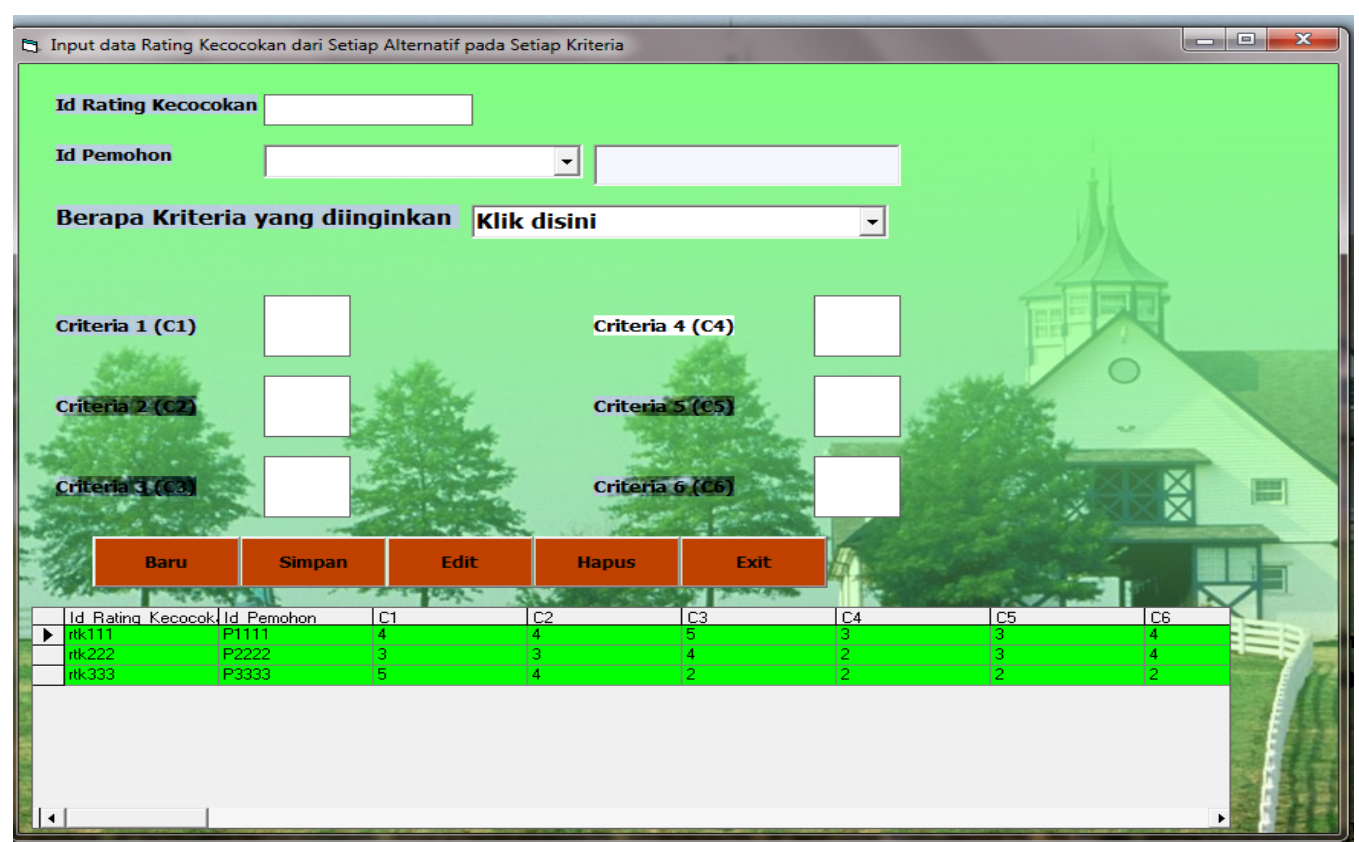

Gambar 3. Tampilan Form Kriteria 


\begin{tabular}{|c|c|c|c|c|c|c|}
\hline \multirow[b]{3}{*}{ Id_Pemohon } & \multirow[b]{3}{*}{ Nama_Pemohon } & \multicolumn{5}{|c|}{$\frac{\text { LAPORAN DATA PEMOHON KPR }}{\text { MENGGUNAKAN METODE FUZZY }}$} \\
\hline & & \multirow[b]{2}{*}{ Tempat_lahir } & \multirow[b]{2}{*}{ Tanggal_lahir } & \multicolumn{2}{|c|}{ Dicetak Tang gal : } & 10-Jul-2014 \\
\hline & & & & Usia & Jenis_Kelamin & Pekerjaa \\
\hline P1111 & Suwandi Tarigan & Berastagi & 4/13/1973 12:00:00.AM & 41 & Laki-laki & Wira Swasta \\
\hline P2222 & Tristan Malik & Medan & 5/7/1985 12:00:00AM & 29 & Laki-laki & Peg Swasta \\
\hline P3333 & Sri Rahma Nally & Medan & 2/3/1978 12:00:00AM & 36 & Perempuan & Peg Swasta \\
\hline
\end{tabular}

Gambar 4. Output Data Pemohon KPR

\section{HASIL FSAW MADM}

MENGGUNAKAN METODE FUZZY SAW MADM

\begin{tabular}{|c|c|c|c|}
\hline & FMADM & : & FS AW AD 11 \\
\hline Id & Pemohonl & : & P1111 \\
\hline Id & Pemohon2 & : & $\mathrm{P} 2222$ \\
\hline & Pemohon 3 & : & P3333 \\
\hline
\end{tabular}

Gambar 5. Output Hasil Perhitungan FSAW MADM

\section{KESIMPULAN}

Aplikasi Sistem Pengambilan Keputusan menampilkan pemohon kredit rumah yang mendapat ranking tertinggi atau nilai terbesar sebagai pertimbangan bagi pengambil keputusan untuk disetujui. Aplikasi Sistem Pengambilan Keputusan untuk Kredit Perumahan Rakyatyang dapat mempermudah dan mempercepat proses persetujuan sesuai hasil kriteria yang diajukan.

Sistem ini dapatmembantu pihak bank yang membutuhkan dukungan sistem yang cepat dalam penentuan pembeli KPR berdasarkan bobot dan kriteria yang lebih banyak dan menghindari nepotisme pihak bank dengan calon pembeli.

\section{SARAN}

Diharapkan para pengambil keputusan (decision maker)memilih pelanggan yang sesuai memenuhi syarat dan hasil sistem sehingga kredit rumah tidak mengalami kredit macet. Pihak bank dapat menambahkan input yang lebih banyak atau randomdengan bobot dan kriteria yang lebih banyak pula. 


\section{DAFTAR PUSTAKA}

Edy Mulyanto,T.Sutojo dan Dr.Vincent Suhartono. (2011). Kecerdasan Buatan. Yogyakarta: PenerbitAndi.

Efraim, Jay dan Ting Peng (2005). Decision Support System and Intelegent Systems (SistemPendukung Keputusan dan Sistem Cerdas). Edisi 7, Jilid 2. Yogyakarta: Andi.

Giarrantano dan Riley (1994). Expert Systems: Principles And Programming. Massachusetts: Thomson Course Technology.

Hartati, Sri. (2003). Fuzzy Multy-Attribute Decision Making(Fuzzy MADM). Yogyakarta: Penerbit Graha Ilmu.

Kusrini. (2007). Konsep dan Aplikasi Sistem Pendukung Keputusan. Yogyakarta: Penerbit Andi

Kusumadewi, Sri. (2003). Artificial Intelligence. Yogyakarta:PenerbitGraha Ilmu.

Mc Leod (1995). Sistem Informasi Manajemen: Studi Sistem Informasi Berbasis Komputer. Jilid II.New Jersey:Prentice-Hall International.

Russe Stuart (1995). Artificial Intelligence a Modern Approach.Jersey: Prentice-Hall International.

Turban, E. (1995). Decision Support and Expert System; Management Support System. Newyork:Prentice-Hall.

Turban, E. (1998). Decision Support and Expert System; Management Support System. ${ }^{5 \text { th }}$ Ed., Newjersey: Prentice-Hall.

\section{BIODATA PENULIS}

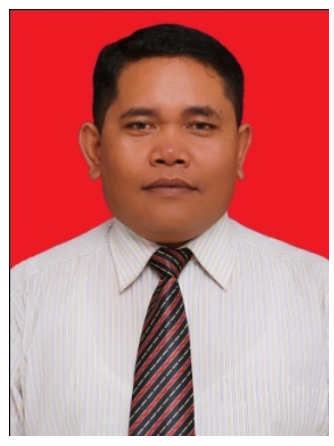

Marganda Simarmata, menyelesaikan S1 Matematika konsentrasi bidang Sain Komputer pada Universitas Sisingamangaraja XII Medan dan mendapat Gelar Sarjana Sains (S.Si) pada tahun 1998. Menyelesaikan Program Pasca Sarjana (S2) Magister of Arts di STTII Medan dengan gelar MA pada tahun 2008. Aktif mengajar dibidang Komputer Aplikasi, Algoritma dan Pemrograman, Struktur Data, Komputer Grafik dan Kecerdasan Buatan. Selain menjadi Dosen di Program Studi Teknik Informatika STMIK Sisingamangaraja XII, juga menjabat sebagai Ketua Program Studi Teknik Informatika dan Wakil Ketua II STMIK Sisingamangaraja XII Medan. Saat ini sedang menyelesaikan studi Pasca Sarjana (S2) Program Studi Teknik Informatika pada Fakultas Ilmu Komputer dan Teknologi Informasi Universitas Sumatera Utara Medan.

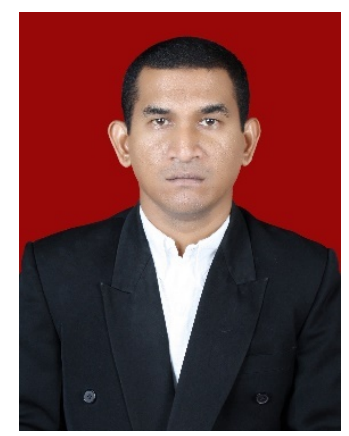

Dahlan Abdullah, Menyelesaikan Pendidikan Strata Satu (S1) Program Studi Teknik Informatika Fakultas Teknologi Industri pada Universitas Islam Indonesia (UII) Yogyakarta dan mendapat Gelar Sarjana Teknik (ST) pada tahun 1999. Menyelesaikan Program Pasca Sarjana (S2) Magister Komputer di STMIK Eresha Jakarta pada tahun 2014 serta saat ini tahun 2015 sedang menjalani studi di Program Doktor (S3) Ilmu Komputer Universitas Sumatera Utara Medan, Aktif melakukan Penelitian dibidang Jaringan Komputer, Database, Radio Net, Komputer Aplikasi, Robotika, Web Based Application, Sistem Informasi Manajemen dan Infrastruktur Jaringan Komputer. Selain menjadi Dosen di Jurusan Teknik Informatika Fakultas Teknik Universitas Malikussaleh, pernah menduduki Jabatan sebagai Kepala UPT. Pusat Komputer Universitas Malikussaleh dari tahun 2005 sampai dengan 2011 dan Jabatan Saat ini sebagai Kepala UPT. Perpustakaan Universitas Malikussaleh Aceh-Indonesia. 